\title{
THE ROLE OF REPLACEMENT FLUIDS IN THE MANAGEMENT OF HAEMORRHAGIC SHOCK: AN EXPERIMENTAL STUDY*
}

\author{
R. Rajagopalan, M.D.(anaesth.), G. C. Tandan, F.F.A.R.C.S.(eng.), F.A.M.S., \\ AND G. R. GODE, F.F.A.R.C.S. (ENG.) †
}

THE ROLE of cardiac output, blood volume, and peripheral resistance in haemorrhagic shock have been well studied, but changes in the interstitial fluid which occupies 15 per cent of the body weight have received little attention. This is remarkable in view of the fact that this huge pool of water, electrolytes, and metabolic components appears now to be a functional mobile fluid which responds very quickly to changes in environment. Though there are many methods, both direct and indirect, for measuring intravascular fluid, which represents only one-fourth of the total extracellular fluid, no method was available for the measurement of extravascular, extracellular fluid for a long time, since it is relatively inaccessible for analysis. Recently, indirect methods of measuring entire extracellular fluid volume have been attempted using sucrose, inulin, and radioactive labelled sulphur. ${ }^{1-3}$

Extracellular fluid plays an important role in the pathophysiology of haemorrhagic shock. One of the constant phenomena associated with the development of irreversible haemorrhagic shock in animals is the loss of extracellular fluid into the lumen and wall of the bowel. Correlated with this observation is the occurrance of haemoconcentration in animals that do not survive, even though shed blood is returned. ${ }^{*}$ This report describes an experimental study undertaken to evaluate the comparative usefulness of blood, lactated Ringer's solution, dextran, and low-molecular-weight dextran in dogs, after subjecting them to rapid removal of 50 per cent of their blood volume:

\section{METHOD}

Experiments were conducted in 32 healthy adult mongrel dogs of either sex, weighing 8 to $20 \mathrm{~kg}$. No premedication was given. They were induced intravenously with $20 \mathrm{mg}$ of thiopentone per $\mathrm{kg}$ body weight, and anaesthesia was maintained with a gas mixture of oxygen 30 per cent and nitrous oxide 70 per cent, allowing the animals to breathe spontaneously through a Magill's semiclosed circuit, with the expiratory valve open. Traces of ether were added initially, in the prehaemorrhagic stage of the experiment only, to produce a tranquil state.

${ }^{\circ}$ From the Department of Anaesthesiology, All India Institute of Medical Sciences, Ansari Nagar, New Delhi 16, India.

$\nmid$ Dr. Rajagopalan is postgraduate resident, Dr. Tandan is Professor of Anaesthesiology, and Dr. Gode is Assistant Professor of Anaesthesiology at the All India Institute of Medical Sciences, New Delhi, India. 
The dogs were heparinized by intravenous injection of heparin $3 \mathrm{mg} / \mathrm{kg}$ body weight. Mean arterial pressure was monitored by a mercury manometer attached to a cannula in left femoral artery, which was also used for bleeding and taking arterial blood samples for $\mathrm{pH}$ and $\mathrm{PCO}_{2}$ measurements. $\mathrm{PCO}_{2}$ and $\mathrm{pH}$ were estimated directly with $\mathrm{CO}_{2}$ and $\mathrm{pH}$ microelectrodes of the Instrumentation Laboratory $\mathrm{PCO}_{2}, \mathrm{Po}_{2}$ and $\mathrm{pH}$ instantaneous recording system. Base excess was calculated from the Sigaard Andersen ${ }^{5}$ nomogram for blood acid-base calculation. The right femoral vein was cannulated for infusion of fluids. Central venous pressure was monitored by a water manometer attached to a cannula placed in superior vena cava through the left external jugular vein.

A fixed volume of blood equivalent to $40 \mathrm{ml} / \mathrm{kg}$ body weight for each dog was drawn at a steady rate over a period of ten minutes into sterile calibrated bottles containing $15 \mathrm{mg}$ of heparin. Haemorrhagic hypotension thus produced was maintained for one hour, at the end of which time the animals were divided randomly into four groups of eight each, for the purpose of infusing different fluids. In group 1 (control group) all the blood withdrawn was retransfused. In group 2 lactated Ringer's solution" was infused equivalent to the amount of blood removed. In group 3 the depleted blood volume was replaced by an equivalent amount of standard dextran. In group 4 an equivalent amount of low-molecularweight dextran (Lomodex) was infused to replace the depleted blood volume.

Throughout the experiment, changes in heart rate, mean arterial pressure, and central venous pressure were observed and recorded every ten minutes. Arterial $\mathrm{pH}$ and $\mathrm{PCO}_{2}$ were measured and base excess or deficit estimated by the Siggaard Andersen nomogram from time to time, (1) before commencing bleeding, (2) soon after bleeding, (3) before transfusion, (4) soon after transfusion, (5) every 15 minutes for one hour after retransfusion.

At the end of the replacement of fluids, anaesthesia was discontinued. Dogs were kept on the table for another hour, by gentle restraint when necessary, to permit us to follow the changes in various parameters. An animal was considered a survivor if it was alive 48 hours after the conclusion of the experiment.

\section{REsULTS}

\section{Survival/mortality rate}

The survival and mortality among the 32 dogs studied and the percentage of survival in each group are given in Table I. It is seen that out of eight control animals in whom blood was transfused, six survived. Five of the eight dogs treated with lactated Ringer's solution, four of those treated with Lomodex, and only three out of eight dogs treated with dextran survived. The highest survival rate (75\%) was obtained with blood retransfüsion. The next best survival rate (62.5\%) was obtained with lactate Ringer's solution. Survival of the dextran-treated group is significantly lower than that of both control dogs and those treated with lactated Ringer's solution.

'Each litre of lactated Ringer's solution contains dextrose $50 \mathrm{gm}$, sodium ions $130 \mathrm{mEq}$, potassium ions $5.4 \mathrm{mEq}$, calcium ions $3.0 \mathrm{mEq}$, chloride ions $111 \mathrm{mEq}$, and lactate ions 28 $\mathrm{mEq}$. 
TABLE I

Survival Rates

\begin{tabular}{lcccr}
\hline \multicolumn{1}{c}{ Group } & $\begin{array}{c}\text { Total } \\
\text { dogs }\end{array}$ & Died & Survived & $\begin{array}{r}\text { Per cent } \\
\text { survival }\end{array}$ \\
\hline 1. Blood & 8 & 2 & 6 & 75.0 \\
2. Lactated Ringer's solution & 8 & 3 & 5 & 62.5 \\
3. Dextran & 8 & 5 & 3 & 37.5 \\
4. Lomodex & 8 & 4 & 4 & 50.0 \\
\hline
\end{tabular}

\section{Changes in mean arterial pressure}

Table II compares mean arterial pressure changes between those dogs that survived and. those that died. A remarkable feature observed was that there was no significant decline in the average mean arterial pressure in those dogs that died as compared to those that survived, in any of the four groups, either before or after replacement of depleted blood volume. In fact, in the dextran group, which gave the lowest survival rate, the average post-transfusion mean arterial pressure was even higher in the animals that died than in those that survived.

TABLE II

Average Mean Arterial Pressure ( $\mathrm{mm} \mathrm{Hg}$ )

\begin{tabular}{lccc}
\hline \hline Group & $\begin{array}{c}\text { Before } \\
\text { haemorrhage }\end{array}$ & $\begin{array}{c}\text { One hour after } \\
\text { haemorrhage }\end{array}$ & $\begin{array}{c}\text { One hour after } \\
\text { transfusion }\end{array}$ \\
\hline $\begin{array}{l}\text { 1. Blood } \\
\text { survived } \\
\text { died }\end{array}$ & 138 & 49.5 & 110.3 \\
$\begin{array}{l}\text { 2. Lactated Ringer's solution } \\
\text { survived } \\
\text { died }\end{array}$ & 142 & 50 & 100 \\
$\begin{array}{l}\text { 3. Dextran } \\
\text { survived } \\
\quad \text { died }\end{array}$ & 136 & 46 & 118 \\
4. Lomodex & 134 & 41 & 108 \\
$\quad \begin{array}{l}\text { survived } \\
\text { died }\end{array}$ & 142 & 45 & 110.3 \\
\hline
\end{tabular}

Changes in central venous pressure

Table III shows average central venous pressure changes in the different groups of dogs, whether they survived or died. Central venous pressure changes between those dogs that survived and those that died and comparisons between mean arterial and central venous pressures in animals that died are shown in Table IV. While central venous pressure had risen to near pre-haemorrhagic level following replacement of depleted blood volume in those dogs that survived, it did not rise significantly and remained considerably lower than pre-haemorrhagic levels in those dogs that died. Even after replacement of the depleted blood volume, central venous pressure did not attain an average of $5 \mathrm{~cm}$ water in those dogs that died. Furthermore, it will be observed that continued low central venous pressure in spite of a significant rise in mean arterial pressure indicated a poor prognosis (Table IV). The changes in mean arterial and venous pressures in each group are shown in Figures $1-4$. 
TABLE III

Central Venous Pressure Changes ( $\mathrm{cm} \mathrm{H}_{2} \mathrm{O}$ )

\begin{tabular}{|c|c|c|c|}
\hline Group & $\begin{array}{c}\text { Before } \\
\text { haemorrhage }\end{array}$ & $\begin{array}{c}\text { One hour after } \\
\text { haemorrhage }\end{array}$ & $\begin{array}{c}\text { One hour after } \\
\text { transfusion }\end{array}$ \\
\hline $\begin{array}{l}\text { 1. Blood } \\
\text { survived } \\
\text { died }\end{array}$ & $\begin{array}{l}7.9 \\
8.2\end{array}$ & $\begin{array}{l}2.5 \\
2.75\end{array}$ & $\begin{array}{l}7.6 \\
3.75\end{array}$ \\
\hline $\begin{array}{l}\text { 2. Lactated Ringer's solution } \\
\text { survived } \\
\text { died }\end{array}$ & $\begin{array}{l}8.1 \\
8.1\end{array}$ & $\begin{array}{l}2.4 \\
2.3\end{array}$ & $\begin{array}{l}8.2 \\
4.3\end{array}$ \\
\hline $\begin{array}{l}\text { 3. Dextran } \\
\text { survived } \\
\text { died }\end{array}$ & $\begin{array}{l}8.9 \\
8.65\end{array}$ & $\begin{array}{l}3.0 \\
2.5\end{array}$ & $\begin{array}{l}7.1 \\
4.3\end{array}$ \\
\hline $\begin{array}{l}\text { 4. Lomodex } \\
\text { survived } \\
\text { died }\end{array}$ & $\begin{array}{l}7.1 \\
7.25\end{array}$ & $\begin{array}{l}2.5 \\
1.75\end{array}$ & $\begin{array}{l}7.5 \\
3.8\end{array}$ \\
\hline
\end{tabular}

TABLE IV

Comparative Changes in Mean Arterial Pressure (Map, $\mathrm{mm} \mathrm{Hg}$ ) and Central Venous Pressure ( $\mathrm{Cr}, \mathrm{cm} \mathrm{H} \mathrm{H}_{2} \mathrm{O}$ ) in Animals That Died

\begin{tabular}{|c|c|c|c|c|c|c|c|c|}
\hline & \multicolumn{2}{|c|}{$\begin{array}{l}\text { Group } 1 \\
\text { (blood) }\end{array}$} & \multicolumn{2}{|c|}{$\begin{array}{l}\text { Group 2 } \\
\text { (lactated } \\
\text { Ringer's } \\
\text { solution) }\end{array}$} & \multicolumn{2}{|c|}{$\begin{array}{c}\text { Group } 3 \\
\text { (dextran) }\end{array}$} & \multicolumn{2}{|c|}{$\begin{array}{c}\text { Group } 4 \\
\text { (Lomodex) }\end{array}$} \\
\hline & MAP & $\mathrm{CVP}$ & MAP & CVP & MAP & CVP & MAP & CvP \\
\hline Before haemorrhage & 142 & 8.2 & 134 & 8.1 & 138 & 8.65 & 141 & 7.25 \\
\hline One hour after haemorrhage & 50 & 2.75 & 41 & 2.3 & 43 & 2.5 & 43 & 1.75 \\
\hline One hour after transfusion & 100 & 3.75 & 108 & 4.3 & 116 & 4.3 & 101 & 3.8 \\
\hline
\end{tabular}

\section{Acid-base changes}

Table $\mathrm{V}$ and Figures 5-8 show the blood changes in $\mathrm{pH}, \mathrm{PCO}_{2}$, and base excess/ deficit in different groups at various stages of the experiments.

In this study, next to blood retransfusion, the best survival rate of 62.5 per cent was obtained with lactated Ringer's solution. The metabolic acidosis in this group was least marked, being even less than that in the blood group. To start with, all the dogs presented a normal acid-base balance, as evidenced by normal values of $\mathrm{pH}, \mathrm{PCO}_{2}$, and base excess/deficit. It is seen that as the process of haemorrhagic hypotension continued, there was a gradual onset of acidosis. That the eventual acidosis is of metabolic origin is revealed by the finding that the fall in $\mathrm{pH}$ is accompanied by a fall in $\mathrm{PCO}_{2}$ and a progressive rise in base deficit. Metabolic acidosis was more or less of the same degree in all four groups, in animals that ultimately survived or died, till retransfusion was started. The average decline in $\mathrm{pH}$ following one hour of haemorrhagic hypotension and before retransfusion varied from 7.28 to 7.32 , average $\mathrm{PcO}_{2}$ varied from 29 to $34 \mathrm{~mm} \mathrm{Hg}$, and base deficit varied between -9.00 and -12.5 . In response to the replacement of depleted blood volume by blood or one of the other fluids, the alterations in $\mathrm{pH}, \mathrm{PCO}_{2}$, and base deficit observed in each group varied according to whether 


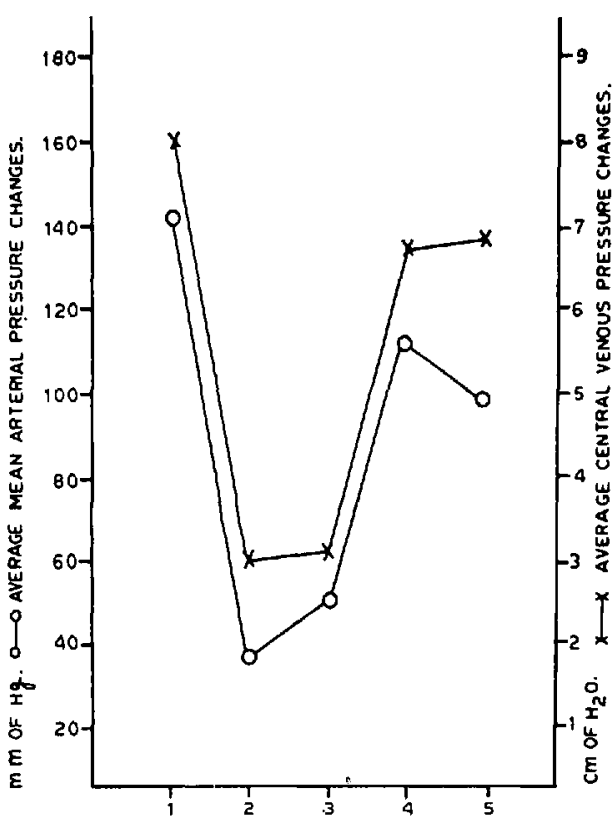

Figure 1. Average mean arterial and central venous pressure changes in group 1 . Stages of experiment: (1) prehaemorrhagic, (2) soon after haemorrhage, (3) one hour after haemorrhage, (4) soon after transfusion, (5) one hour after transfusion.

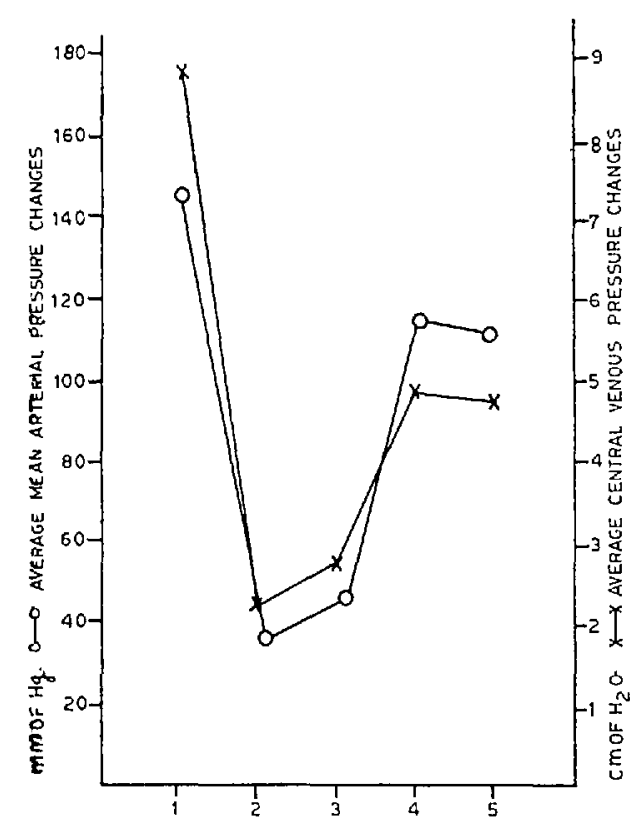

Ficune 3. Average mean arterial and central venous pressure changes in group 3 . Stages as in Figure 1.

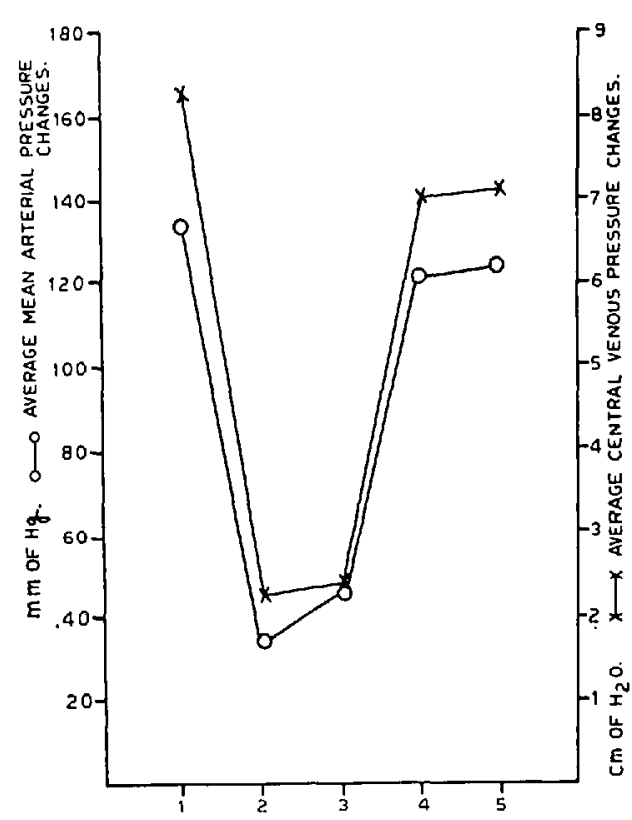

Figure 2. Average mean arterial and central venous pressure changes in group 2. Stages as in Figure 1.

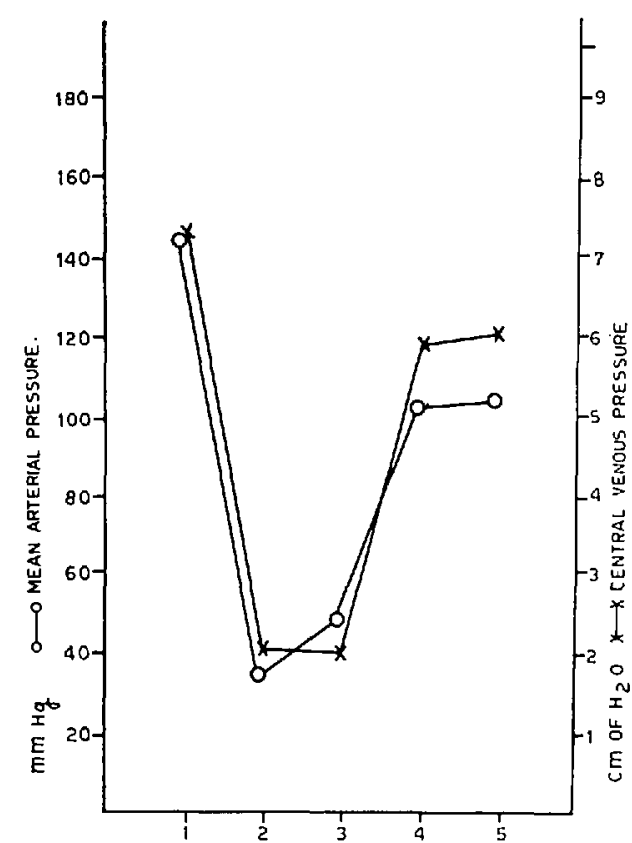

FIcure 4. Average mean arterial and central venous pressure changes in group 4 . Stages as in Figure 1. 


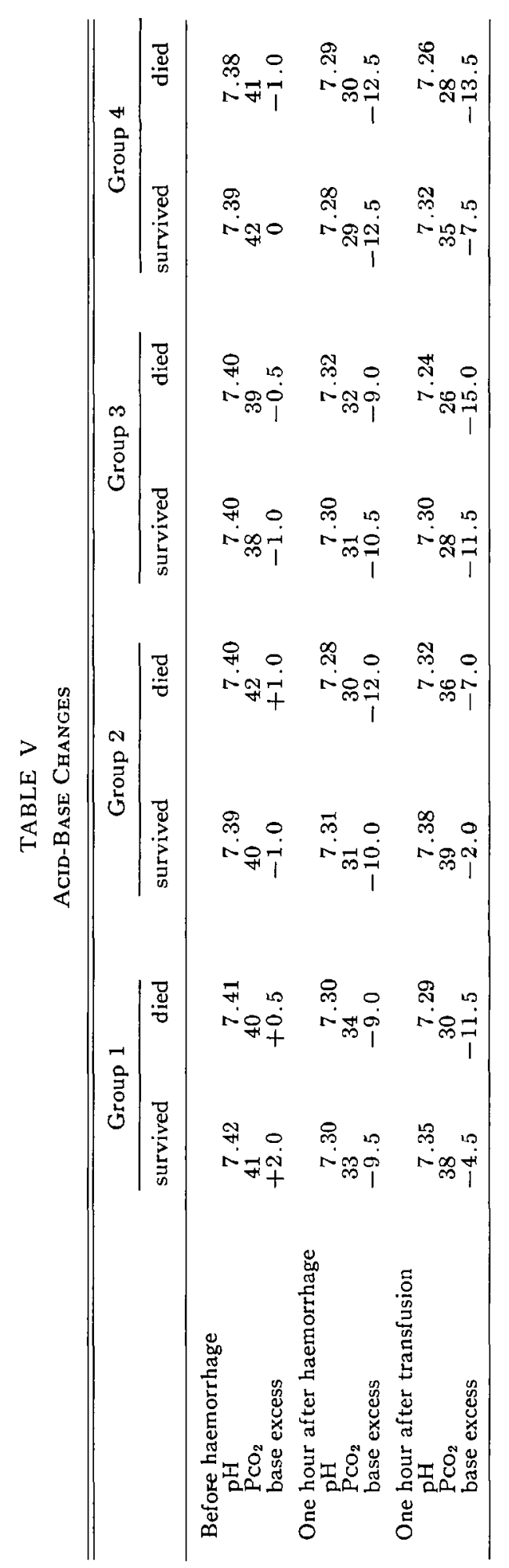




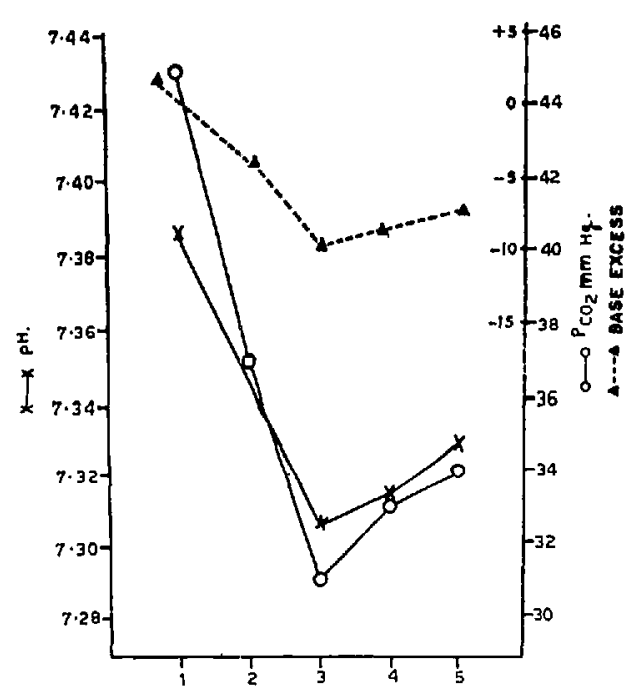

Figure 5. Base excess, $\mathrm{pH}$, and $\mathrm{PcO}_{2}$ changes in group 1. Stages as in Figure 1.

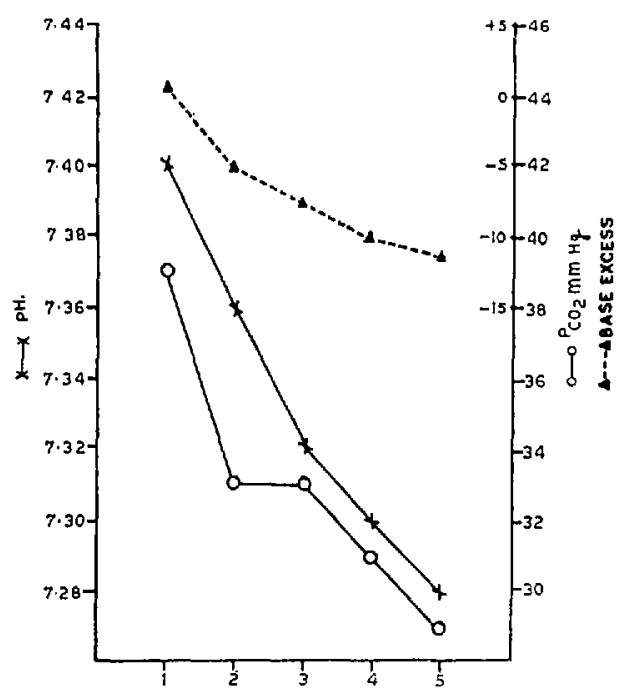

Figure 7. Base excess, $\mathrm{pH}$, and $\mathrm{Pco}_{2}$ changes in group 3. Stages as in Figure 1.

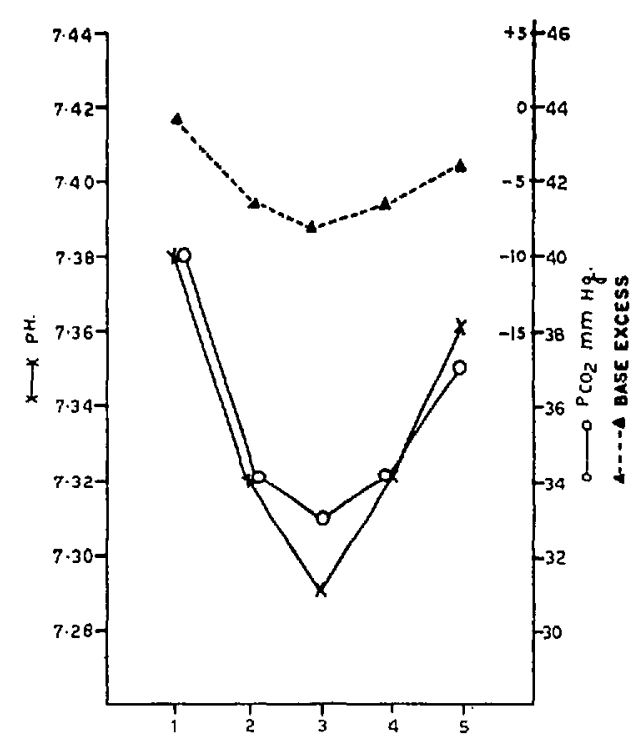

Figure 6. Base excess, $\mathrm{pH}$, and $\mathrm{PCO}_{2}$ changes in group 2. Stages as in Figure 1.

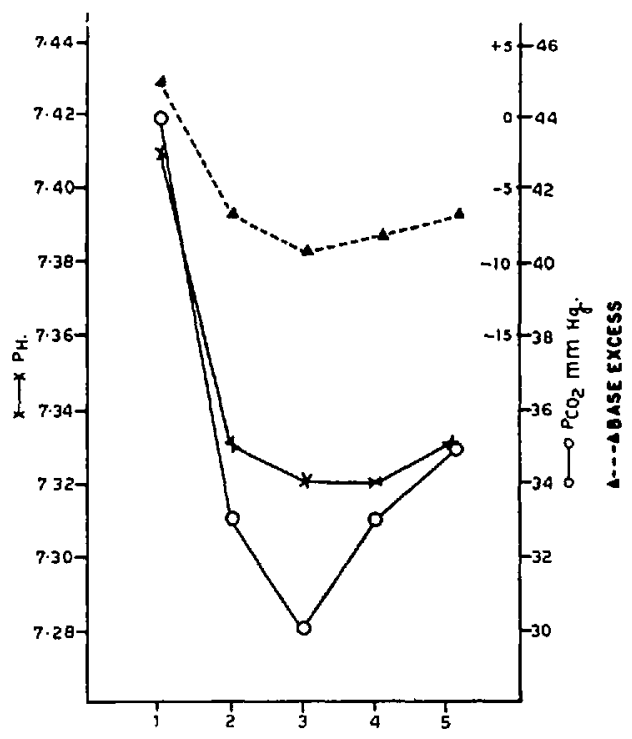

Figure 8. Base excess, $\mathrm{pH}$, and $\mathrm{PcO}_{2}$ changes in group 4. Stages as in Figure 1.

the animal survived or died. In group 1 (blood) the animals that survived showed a rise in base excess from -9.5 to -4.5 , whereas in those that died the base excess continued to decline from -9 to -11.5 . The animals in group 2 (lactated Ringer's solution) showed the least amount of base deficit following retransfusion. In the animals that survived, the base excess rose from -10 to -2 . Even the animals that died in this group showed an improvement in their metabolic status 
by a rise of $\mathrm{pH}$ from 7.28 to 7.32 , a rise of $\mathrm{PCO}_{2}$ from $30 \mathrm{~mm} \mathrm{Hg}$ to $36 \mathrm{~mm} \mathrm{Hg}$, and a rise of base excess from -12 to -7.00 . Group 3 (dextran) showed maximum metabolic upheaval. It was observed that all the animals, whether they survived or died, continued to show a deterioration of metabolic status even after retransfusion. In the animals that survived, the $\mathrm{PCO}_{2}$ and base deficit kept on falling from 31 to $28 \mathrm{~mm} \mathrm{Hg}$ and base excess from -10.5 to -11.5 respectively one hour after retransfusion. In the animals that died in this group a similar picture was observed, and base excess declined from -9.0 one hour after haemorrhage to -15.0 one hour after transfusion. In group 4 (low molecular dextran), the metabolic status was slightly better than that in the dextran group, but inferior to that in groups 1 and 2 . In this group it was observed that animals that survived showed a rise in base excess from -12.5 to -7.5 . However in animals that died there was a progressive fall of base excess from -12.5 following haemorrhage to -13.5 one hour after transfusion. It will thus be observed that infusions of lactated Ringer's solution showed a tendency to restore normal acid-base balance even more than did blood replacement.

\section{Discussion}

There is little dispute over the consensus that the most efficacious therapy in the management of haemorrhagic shock is prompt, rapid, and adequate replacement of lost circulating blood volume by blood itself. Prolonged controversy exists, however, conceming the proper role and usefulness of various blood volume expanders in the absence of the availability of blood. Various degrees of superiority are being claimed by different workers favouring one blood volume expander over another. It is of interest that Coller $e t a l .{ }^{6}$ and Shires and Jackson ${ }^{7}$ in published reports 18 years apart, presented diametrically opposed results and conclusions, the former saying that no salt solution should be given at all and the latter advocating free use of balanced salt solutions.

Fox ${ }^{8}$ had stated, "If the vascular compartment were an inflexible system of rigid pipes and if 3 litres of blood were lost in such a system containing 7 litres, 3 litres of blood transfusion would presumably refill the system and achieve complete restoration of vital functions. The vascular compartment, however, is different. It is a flexible system of vessels which constrict and dilate; the walls of these vessels are semipermeable and are suspended in interstitial fluid which surrounds tissue cells." Further evidence of the role of interstitial fluid in haemorrhagic shock is provided by the work of Gilman, ${ }^{9}$ who demonstrated that animals deficient in extracellular volume are markedly sensitive to even a small haemorrhage. Reynolds ${ }^{10}$ has shown that dogs treated with salt solutions alone show good survival and return of cardiac output. In addition, arterio-venous oxygen saturation difference was restored to normal, and even though complete restoration of oxygen-carrying capacity was not achieved, normal tissue oxygenation was accomplished. Wolfman ${ }^{11}$ and Shires ${ }^{12}$ have shown enhanced survival rates with the administration of balanced salt solutions in the management of haemorrhagic shock. 
In this study, next to blood, the best survival rate of 62.5 per cent was obtained with infusion of lactated Ringer's solution. The metabolic acidosis in this group was least marked, being even less than that in the blood group.

It is noteworthy that, in this study, there has been a definite correlation between central venous pressure and the mortality/survival rate, while there has been no such correlation between mean arterial pressure and the mortality/survival rate (Table IV). It is also interesting to note that those dogs which showed low central venous pressure even on retransfusion invariably exhibited significant metabolic acidosis. That the severity of shock varies pari passu with the severity of metabolic acidosis has been accepted. Cannon, ${ }^{13}$ as long ago as 1923 , noted a rough correlation between the severity or duration of hypotension and the decrease in the carbon-dioxide-combining power of blood. Gibson and his collaborators ${ }^{14}$ showed an uncompensated metabolic acidosis developing with different forms of shock.

Possibly the judicious combination of whole blood and Ringer's lactate transfusions may produce the most satisfactory response in the management of haemorrhagic shock.

\section{SUMMARY}

An experimental study was undertaken in 32 healthy mongrel dogs to evaluate the comparative usefulness of blood, lactated Ringer's solution, dextran, and low molecular weight dextran in the management of haemorrhagic shock. Changes in mean arterial pressure, central venous pressure, acid-base state, and survival rate were studied and compared.

Lactated Ringer's solution was found to be a promising replacement fluid, ranking next to blood. It increased central venous pressure and controlled the metabolic acidosis.

Continuous central venous pressure monitoring was found to be a more reliable guide than mean arterial pressure monitoring in the management of shock. Changes in the central venous pressure correlated well with the survival rate and the state of metabolic acidosis.

\section{RÉSUMÉ}

Nous avons fait une étude expérimentale chez 32 chiens bâtards en bonne santé pour établir la valeur pratique comparée du sang, du lactate Ringer, du dextran et du dextran à faible poids moléculaire dans le traitement du choc hémorragique. Nous avons étudié et comparé la tension artérielle moyenne, la tension veineuse centrale, l'équilibre acide-base et le taux de survivance.

Comme liquide de remplacement, le lactate Ringer s'est avéré un fluide prometteur, sa plaçant voisin du sang. Il augmente la tension veineuse centrale et contrôle l'acidose métabolique.

L'enregistrement continuel de la tension veineuse centrale s'est révélé un guide plus fiable que celui de la tension artérielle moyenne dans le traitement du choc. Les changements de la tension veineuse centrale sont en corrélation étroite avec le taux de survivance et le degré d'acidose métabolique. 


\section{REFERENCES}

1. Gamble, J. L.; Robertson, J. S.; Hanningan, C. A.; Foster, C. G.; \& Farr, L. E. Chloride, Bromide, Sodium and Sucrose Spaces in Man. J. Clin. Invest. 26: 1088 (1947).

2. Cotrove, E. Mechanisms and Extent of Distribution of Inulin and Sucrose in Chloride Space of Tissues. Am. J. Physiol. 176: 396 (1954).

3. Ryan, R. J.; Pascal, L. R.; Inoye, T.; \& Bernstein, L. Experiences with Radiosulfate in Estimating Physiologic Extracellular Water in Healthy and Abnormal Man. J. Clin. Invest. 35: 1119 (1956).

4. Wigcers, H. D. \& Ingraham, R. C. Haemorrhagic Shock: Definition of Criteria for Its Diagnosis. J. Clin. Invest. 25: 30 (1946).

5. SicgaArd-Andersen, O. Blood Acid-base Alignment Nomogram. Scandinav. J. Clin. Lab. Invest. 15: 211 (1963).

6. Coller, F. A.; Cambell, K. N.; Vaughan, H. H.; Iob, L. V.; \& Moyer, C. A. Postoperative Salt Intolerance. Ann. Surg. 119: 533 (1944).

7. Shires, T. \& Jackson, D. E. Postoperative Salt Intolerance. Arch. Surg. 84: 703 (1962).

8. Fox, C. L. \& Lasker, S. E. Fluid Therapy in Surgical Emergencies. Surg. Clin. N. Am. 35: 335 (1955)

9. Gilman, A. Experimental Sodium Loss Analogous to Adrenal Insufficiency: The Resulting Water Shift and Sensitivity to Haemorrhage. Am. J. Physiol. 146: 348 (1946).

10. Reynolds, M. Cardiovascular Effects of Large Volumes of Isotonic Saline Infused Intravenously into Dogs Following Severe Haemorrhage. Am. J. Physiol. 158: 418 (1949).

11. Wolfman, E. F., JR.; Neml, S. A.; Heaps, B. S.; \& Zuidema, G. D. Donor Blood and Isotonic Salt Solution. Arch. Surg. 86: 869 (1963).

12. Shires, T.; Dale, C.; Carrico, J.; \& Lightfoot, S. Fluid Therapy in Haemorrhage Shock. Arch. Surg. 88: 688 (1964).

13. Cannon, W. B. Traumatic Shock. Appleton Century-Crofts (1923).

14. Gibson, J. G. 2nd; Seligman, A. M.; Peacock, W. C.; Fine, J.; Aub, J. C.; \& Evans, R. D. The Circulating Red Cell and Plasma Volume and the Distribution of Blood in Large and Minute Vessels in Experimental Shock in Dogs, Measured by Radioactive Isotopes of Iron and Iodine. J. Clin. Invest, 26: 126 (1947). 